\title{
Protocol for maximizing the triglycerides-enriched lipids production from Dunaliella salina SA32007 biomass, isolated from the Salar de Atacama (Northern Chile)
}

\author{
Diana Arias-Forero ${ }^{1 *}$, Gladys Hayashida ${ }^{1}$, Mario Aranda ${ }^{2}$, Solange Araya ${ }^{1}$, Tamara Portilla ${ }^{1}$, \\ Andreína García ${ }^{3}$, Paula Díaz-Palma ${ }^{3}$ \\ ${ }^{1}$ Department of Chemistry, Faculty of Sciences, Universidad Católica del Norte, Antofagasta, Chile \\ ${ }^{2}$ Laboratory of Advance Research on Foods and Drugs, Department of Food Science, Nutrition and Dietetics, Faculty of Pharmacy, \\ Universidad de Concepción, Concepción, Chile \\ ${ }^{3}$ Advanced Mining Technology Center (AMTC), Faculty of Physic and Mathematics Sciences, Universidad de Chile, Santiago, Chile \\ Email: *darias@ucn.cl
}

Received 18 April 2013; revised 21 May 2013; accepted 17 June 2013

Copyright (C) 2013 Diana Arias-Forero et al. This is an open access article distributed under the Creative Commons Attribution License, which permits unrestricted use, distribution, and reproduction in any medium, provided the original work is properly cited.

\begin{abstract}
This paper reports the effects of different culture conditions for Dunaliella salina SA32007 from Salar de Atacama (second Region, northern of Chile) over biomass, lipid production and triglycerides synthesis. A maximum value of microalgae density $(8.2 \times 109$ Cells/L) and an intrinsic growth rate (0.17 d-1), were obtained using a culture with $0.5 \mathrm{~mol} / \mathrm{L}$ of $\mathrm{NaCl}$ and a nitrogen/phosphorous (N/P) limitation of 14/1. The triglycerides production was significantly favoured under nitrogen deficiency conditions (Mann-Whitney test; $p=0.0043$ ). However there was a nitrogen-limiting threshold for the stimulation and accumulation of triglycerides (N/P: 14/1), lower than that limit, these compounds would not be accumulated. It was also observed that triglyceride content was not proportional to the total lipid content and the maximum number of cells. The aeration system employed stimulated the growth and synthesis of structural organic molecules. Regarding microalgae growth stage subjected to nitrogen deficiency, when the deficit was applied before the lag phase, the negative effect on the biomass and the triglycerides production decreased.
\end{abstract}

Keywords: Lipids; Triacilglycerides; Nitrogen Deficiency; Salinity; Dunaliella salina

\section{INTRODUCTION}

There is now a worldwide crisis due to the need of new

*Corresponding author. sources of energy. Various disciplines are looking for new conventional and renewable materials to generate heat energy [1]. Among these, the use of microalgae biomass to produce oil and biodiesel is considered increasingly relevant [2-4]. Biodiesel generated from algae offers many advantages, e.g. during algae photosynthesis the atmospheric $\mathrm{CO}_{2}$ is fixed at a similar rate to that produced during combustion process of biodiesel $[5,6]$, thus, the balance of $\mathrm{CO}_{2}$ pollution generated is virtually zero. In addition, microalgae show a high productivity rate with yields per acre nearly 30 times greater than those of corn or soybeans [7]. However, the oil quality for biodiesel production is not always appropriate because it has low triglycerides content, and high concentration of free fatty acids. The latter can interfere with the trans-esterification process required for the biofuel obtaining [4]. Different culture tests including high salinity and nutrient limitation (e.g. $\mathrm{Mg}, \mathrm{K}, \mathrm{Na}, \mathrm{NO}_{3}$ and $\mathrm{PO}_{4}$ ) can enhance lipid synthesis and particularly triglycerides, but unfortunately these conditions produced a microalgae biomass reduction and therefore, the biodiesel yield also decreases [8-16]. The objective of this study was the assay of specific conditions in salinity and nitrogen deficiency and air bubbling that could stimulate the triglycerides production, while the negative effect over the biomass is mitigated. This will be carried out by a strain of Dunaliella salina SA32007, isolated from the Salar de Atacama, II Region-Chile, in order to potentiate biotechnological properties of the local microorganisms.

Dunaliella salina is a cosmopolitan species living in hypersaline aquatic environments [17]. In Chile there are records of Dunaliella salina in saline lagoons located in Highland Andean Salars, as in Salar de Atacama (North- 
ern, Chile) [18]. High sunlight intensities stimulate this microalgae to produce a variety of carotenoids, being the most abundant in $\beta$-carotene. This pigment is formed as a protective barrier against oxidation due to free radicals caused by sunlight [19]. It is noteworthy that Dunaliella species are recognized primarily for its ability to produce $\beta$-carotene, which is verified by reviewing the vast scientific literature related to this topic [20-23]. Other potentialities of Dunaliella, such as their ability to induce lipids bioaccumulation in large quantities, have also been studied [24].

\section{MATERIAL AND METHODS}

\subsection{Dunaliella salina SA32007 and Media}

D. salina SA32007 strain, isolated from the Salar de Atacama $\left(23^{\circ} 30^{\prime} 0^{\prime \prime} \mathrm{S}, 68^{\circ} 15^{\prime} 0^{\prime \prime} \mathrm{W}\right)$ II Region Antofagasta, Chile, was cultured in two modified versions of Johnson medium [25], one in which the $\mathrm{NaCl}$ concentration changed to vary the salinity (identified from here and beyond as "Medium A") and another that was modified in its N/P ratio (identified from here and beyond as "Medium B").

"Medium A" contained the following (per liter): $\mathrm{NaCl}$ $11.68 \mathrm{~g}(0.2 \mathrm{M}) / 29.2 \mathrm{~g}(0.5 \mathrm{M}) / 58.4 \mathrm{~g}(1 \mathrm{M}) / 116.9 \mathrm{~g}(2$ M)/175.2 g (3 M)/233.6 g (4 M) y $292 \mathrm{~g}(5 \mathrm{M})$; $\mathrm{MgCl}_{2} \cdot \mathrm{H}_{2} \mathrm{O} 1.5 \mathrm{~g} ; \mathrm{MgSO}_{4} \cdot 7 \mathrm{H}_{2} \mathrm{O} 0.5 \mathrm{~g} ; \mathrm{KNO}_{3} 1 \mathrm{~g} ; \mathrm{KCl}$ $0.2 \mathrm{~g} ; \mathrm{CaCl}_{2} 0.2 \mathrm{~g} ; \mathrm{KH}_{2} \mathrm{PO}_{4} 0.071 \mathrm{~g}$ (14/1 N/P Ration, Johnson Medium reference [25]); Tris (hydroxymethyl) aminomethane $2.45 \mathrm{~g}$; EDTA $2 \mathrm{Na} 1.89 \mathrm{mg} ; \mathrm{ZnSO}_{4} \cdot 7 \mathrm{H}_{2} \mathrm{O}$ $0.087 \mathrm{~g} ; \mathrm{H}_{3} \mathrm{BO}_{3} 0.61 \mathrm{mg} ; \mathrm{CoCl} \cdot 6 \mathrm{H}_{2} \mathrm{O} \quad 0.015 \mathrm{mg}$, $\mathrm{CuSO}_{4} \cdot 5 \mathrm{H}_{2} \mathrm{O} 0.06 \mathrm{mg} ; \mathrm{MnCl}_{2} 0.23 \mathrm{~g},\left(\mathrm{NH}_{4}\right)_{6} \mathrm{Mo}_{7} \mathrm{O}_{24} \cdot 4 \mathrm{H}_{2} \mathrm{O}$ $0.38 \mathrm{mg}$; Fe(III)·EDTA $3.64 \mathrm{mg}$; vitamin B1 $0.1 \mathrm{mg}$; vitamin $\mathrm{B} 120.5 \mathrm{mg}$; biotin $0.5 \mathrm{mg}, \mathrm{pH}$ was fixed to 8.0 with $1 \mathrm{~N} \mathrm{HCl}$. Additionally, in this step was tested the $25 / 1 \mathrm{~N} / \mathrm{P}$ ration $\left(\mathrm{KH}_{2} \mathrm{PO}_{4} 0.04 \mathrm{~g}\right)$, corresponding to these determined in the collection strain area.

"Medium B" contained the following (per liter): $\mathrm{KH}_{2} \mathrm{PO}_{4} 2 \mathrm{~g} / 0.2 \mathrm{~g} / 0.071 \mathrm{~g} / 0.04 \mathrm{~g}$ and $\mathrm{KNO}_{3} 1 \mathrm{~g}$ (which resulted in a change in the $\mathrm{N} / \mathrm{P}$ ration equivalent to $0.5 / 1$, 5/1, 14/1, 25/1, respectively); $\mathrm{MgCl}_{2} \cdot \mathrm{H}_{2} \mathrm{O} 1.5 \mathrm{~g}$; $\mathrm{MgSO}_{4} \cdot 7 \mathrm{H}_{2} \mathrm{O} 0.5 \mathrm{~g} ; \mathrm{NaCl} 29.2 \mathrm{~g} ; \mathrm{KCl} 0.2 \mathrm{~g} ; \mathrm{CaCl}_{2} 0.2 \mathrm{~g}$; Tris (hydroxymethyl) aminomethane $2.45 \mathrm{~g}$; EDTA $2 \mathrm{Na}$ $1.89 \mathrm{mg} ; \mathrm{ZnSO}_{4} \cdot 7 \mathrm{H}_{2} \mathrm{O} \quad 0.087 \mathrm{~g} ; \mathrm{H}_{3} \mathrm{BO}_{3} 0.61 \mathrm{mg}$; $\mathrm{CoCl} \cdot 6 \mathrm{H}_{2} \mathrm{O} 0.015 \mathrm{mg}, \mathrm{CuSO}_{4} \cdot 5 \mathrm{H}_{2} \mathrm{O} 0.06 \mathrm{mg} ; \mathrm{MnCl}_{2}$ $0.23 \mathrm{~g},\left(\mathrm{NH}_{4}\right)_{6} \mathrm{Mo}_{7} \mathrm{O}_{24} \cdot 4 \mathrm{H}_{2} \mathrm{O} 0.38 \mathrm{mg}$; $\mathrm{Fe}(\mathrm{III}) \cdot$ EDTA 3.64 $\mathrm{mg}$; vitamin $\mathrm{B} 10.1 \mathrm{mg}$; vitamin $\mathrm{B} 120.5 \mathrm{mg}$; biotin 0.5 $\mathrm{mg}, \mathrm{pH}$ was fixed to 8.0 with $1 \mathrm{~N} \mathrm{HCl}$. The $\mathrm{N} / \mathrm{P}$ rations employed in the "Medium B" were modified from the original recipe of Johnson Medium [25], which presents a N/P ratio of $14 / 1$ corresponding to $\mathrm{KH}_{2} \mathrm{PO}_{4} 0.071 \mathrm{~g}$, and $\mathrm{KNO}_{3} 1 \mathrm{~g}$.

Each culture medium was supplemented with chlor- amphenicol $1 \%$, in order to obtain axenic monocultures.

Experiments were conducted under controlled light and temperature conditions at $30^{\circ} \mathrm{C}$ with an incident white light of $360 \mu \mathrm{mol} / \mathrm{m}^{2} / \mathrm{s}$ and a photoperiod cycle of 15/9 (light/dark). A high light intensity was selected to maintain the optimal conditions for microalgae acclimated to large amounts of light. In fact, measurements of the light incident on the Salar de Atacama often exceed $500 \mu \mathrm{mol} / \mathrm{m}^{2} / \mathrm{s}[26]$.

\subsection{Experimental I: Variation of Salt Concentration of $\mathrm{NaCl}$}

A preliminary screening of salinity-tolerance was performed because the microalgae strain was kept under non-hipersaline culture conditions for more than three years. Fourteen flasks (E-I1-E-I14) with $200 \mathrm{~mL}$ of "Medium A" were inoculated with $10 \mathrm{~mL}$ of axenic culture of D. salina SA32007 (average cell density of $8.0 \times 10^{6}$ cells/L) and incubated at $30^{\circ} \mathrm{C}$ for 30 days. Salinity range varied between $0.2 \mathrm{M}$ and $5.0 \mathrm{M} \mathrm{NaCl}$ as described in Dunaliella salina SA32007 and Media section. Control conditions were set according to the isolation place of the microalgae strain, corresponding to a N/P ratio of $25 / 1$ and a salinity level of $0.5 \mathrm{~mol} / \mathrm{L}$ of $\mathrm{NaCl}$ (Table 1).

\subsection{Experimental II: Variation of N/P Ratio, Air Bubbling and Nitrogen Deficiency}

In this section different N/P ratios were assayed (Table 2) keeping fixed the salinity at $0.5 \mathrm{~mol} / \mathrm{L} \mathrm{NaCl}$, which yielded the maximum biomass value in the experimental I. Additionally, two other variables were included in this step: the air supply using bubbling and the point within the growth curve of the strain where the nitrogen deficiency was applied. In the second case, two treatments were tested: one in which the deficit of nitrogen was applied Before the Latency Phase (BLP-treatments) and another in which the deficit was applied after the latency Phase (ALP-treatments). As regards the air bubbling, treatments with bubbling (Bb-treatments) and without

Table 1. Experimental I: Provided by varying the salt concentration of $\mathrm{NaCl}$. Experimental II: Provide by varying the N/P ratio, the bubbling and the time of application of nitrogen deficiency.

\begin{tabular}{ccccccc}
\hline \multicolumn{7}{c}{ Experimental I: NaCl molar concentration } \\
\hline \multicolumn{7}{c}{ N/P Ratio 14/1 } \\
\hline E-I1: & ${ }^{*}$ E-I2: & E-I3: & E-I4: & E-I5: & E-I6: & E-I7: \\
$0.2 \mathrm{M}$ & $0.5 \mathrm{M}$ & $1 \mathrm{M}$ & $2 \mathrm{M}$ & $3 \mathrm{M}$ & $4 \mathrm{M}$ & $5 \mathrm{M}$ \\
\hline \multicolumn{7}{c}{ N/P Ratio 25/1 } \\
\hline E-I8: & ${ }^{*}$ E-I9: & E-I10: & E-I11: & E-I12: & E-I13: & E-I14: \\
$0.2 \mathrm{M}$ & $0.5 \mathrm{M}$ & $1 \mathrm{M}$ & $2 \mathrm{M}$ & $3 \mathrm{M}$ & $4 \mathrm{M}$ & $5 \mathrm{M}$ \\
\hline
\end{tabular}

${ }^{*}$ Control conditions according to the isolation place of the D. salina SA32007. 
Table 2. Experimental II: Provide by varying the N/P ratio, the bubbling and the time of application of nitrogen deficiency.

\begin{tabular}{cccc}
\hline Treatment & $\begin{array}{c}\text { N/P } \\
\text { Ratio }\end{array}$ & $\begin{array}{c}\text { Air-Bubbling } \\
\text { Protocol }\end{array}$ & $\begin{array}{c}\text { Nitrogen-Deficit } \\
\text { Protocol }\end{array}$ \\
\hline${ }^{*}$ E-II1 & $25 / 1$ & $\mathrm{Bb}$ & $\mathrm{BLP}$ \\
${ }^{*}$ E-II2 & $25 / 1$ & $\mathrm{NBb}$ & $\mathrm{BLP}$ \\
E-II3 & $14 / 1$ & $\mathrm{Bb}$ & $\mathrm{BLP}$ \\
E-II4 & $14 / 1$ & $\mathrm{Bb}$ & ALP \\
E-II5 & $14 / 1$ & $\mathrm{NBb}$ & $\mathrm{BLP}$ \\
E-II6 & $14 / 1$ & $\mathrm{NBb}$ & ALP \\
E-II7 & $5 / 1$ & $\mathrm{Bb}$ & BLP \\
E-II8 & $5 / 1$ & $\mathrm{Bb}$ & ALP \\
E-II9 & $5 / 1$ & $\mathrm{NBb}$ & BLP \\
E-II10 & $5 / 1$ & $\mathrm{NBb}$ & ALP \\
E-II11 & $0.5 / 1$ & $\mathrm{Bb}$ & BLP \\
E-II12 & $0.5 / 1$ & $\mathrm{Bb}$ & ALP \\
E-II13 & $0.5 / 1$ & $\mathrm{NBb}$ & BLP \\
E-II14 & $0.5 / 1$ & $\mathrm{NBb}$ & ALP \\
\hline
\end{tabular}

Abbreviators: Bubbled (Bb); Not Bubbled (NBb); Before Lag Phase (BLP); After Lag Phase (ALP). ${ }^{*}$ Control conditions according to the isolation place of the D. salina SA32007, varying the air bubbling.

bubbling (NBb-treatments) were tested. These treatments were numerated from E-II3 to E-II14 (Table 2). The initial density of each culture averaged $1147 \pm 946 \mathrm{Cells} / \mathrm{L}$. The controls (E-II1 and E-II2) were cultured using the same conditions found at the isolation site of the strain, but varying the bubbling (Table 2).

\subsection{Biomass Quantification}

Microalgal biomass was daily count in duplicate using Neubauer chambers. Microalgae samples were pre-fixed with a 5\% Lugol solution. The maximum number of cells in each culture, measured as the carrying capacity $(\mathrm{K})$, was correlated to its intrinsic growth rate $(\mu)$.

\subsection{Extraction and Quantification of Total Extractable Lipids and Triglycerides}

Lipids from the microalgae pellet obtained after biomass centrifugation, were extracted using the Bligh and Dyer method [27]. Thus, the results represent the Percentage of total extractable lipids (\%TELs) from fresh biomass of the microalgae. The Percentage of Triglycerides (\%TAGs) in total extractable lipids was determined by the glycerol-3-phosphate-oxidase-p-chlorophenol enzymatic method (Triglyceride GOP/PAP AA from Wiener) using triolein as standard $[10,28]$.

Each experimental result was obtained through a triplicated set of data. Standard deviation was calculated in each case. Additionally, the overall effect of different variable tested in this study was statistically validated through the non-parametric significance test of MannWhitney U [29].

\section{RESULTS}

\subsection{Microalgae Growth Curve and Salinity Assays}

Figures 1 (a) and (b) show the growth curves of $D$. salina SA32007 in Media A and B, respectively. Both cultures (N/P ratio of $14 / 1$ and 25/1) showed that microalgae samples cultured with $\mathrm{NaCl}$ levels from $0.2 \mathrm{~mol} / \mathrm{L}$ to $1 \mathrm{~mol} / \mathrm{L}$ maintained a lag phase for a period between 7 and 11 days, followed by the corresponding exponential phase. For treatments with salinities higher than $1 \mathrm{~mol} / \mathrm{L}$ of $\mathrm{NaCl}$ (E-I3-E-I7 and E-I10-E-I14) no culture growth was appreciated and the mean cell density values of the initial inoculum remained unchanged; this was observed regardless of their N/P ratio. The kinetic behaviour of each treatment is summarized in Table 3 . The maximum growth was achieved using $0.5 \mathrm{~mol} / \mathrm{L}$ of $\mathrm{NaCl}$ and a N/P ratio of $14 / 1$ and reached a value of $8.2 \times 10^{9} \mathrm{Cells} / \mathrm{L}$ (Table 3).

\subsection{N/P Ratio, Air Bubbling and Nitrogen Deficiency}

Figure 2(a) indicates the growth curves for microalgae cultures subjected to nitrogen deficiency, applied before and after the lag phase with air bubbling. It was observed

Table 3. Culture conditions and kinetic parameters to $D u$ naliella salina SA32007 in experimental I.

\begin{tabular}{cccccc}
\hline \multicolumn{5}{c}{ Culture Conditions and Kinetic Parameters } \\
\hline Treatment & $\begin{array}{c}\text { NaCl } \\
\text { (Molar) }\end{array}$ & $\begin{array}{c}\text { N/P } \\
\text { Ratio }\end{array}$ & $\begin{array}{c}\text { Maximum } \\
\text { culture } \\
\text { density } \\
\text { K (Cels/L) }\end{array}$ & $\begin{array}{c}\text { Time } \\
\text { generation } \\
g \text { (days) }\end{array}$ & $\begin{array}{c}\text { Instantaneous } \\
\text { growth rate } \\
\mu\left(\mathrm{d}^{-1}\right)\end{array}$ \\
\hline E-I1 & 0.2 & $14 / 1$ & 6165 & 7 & 0.09 \\
E-I2 & 0.5 & $14 / 1$ & 8250 & 4 & 0.17 \\
E-I3 & 1 & $14 / 1$ & 6165 & 7 & 0.09 \\
E-I4 & 2 & $14 / 1$ & $* *$ & - & - \\
E-I5 & 3 & $14 / 1$ & $* *$ & - & - \\
E-I6 & 4 & $14 / 1$ & $* *$ & - & - \\
E-I7 & 5 & $14 / 1$ & $* *$ & - & - \\
E-I8 & 0.2 & $25 / 1$ & 6285 & 3 & - \\
E-I9 & 0.5 & $25 / 1$ & 5040 & 3 & 0.23 \\
E-I10 & 1 & $25 / 1$ & 5610 & 4 & 0.17 \\
E-I11 & 2 & $25 / 1$ & $* *$ & - & - \\
E-I12 & 3 & $25 / 1$ & $* *$ & $*$ & - \\
E-I13 & 4 & $25 / 1$ & $* *$ & & - \\
E-I14 & 5 & $25 / 1$ & $* *$ & & - \\
\hline
\end{tabular}

${ }^{*}$ Control conditions: N/P ration of $25 / 1$ and salinity of $0.5 \mathrm{M}$ as $\mathrm{NaCl} ;{ }^{* *} \mathrm{No}$ cellular growth was determined. 


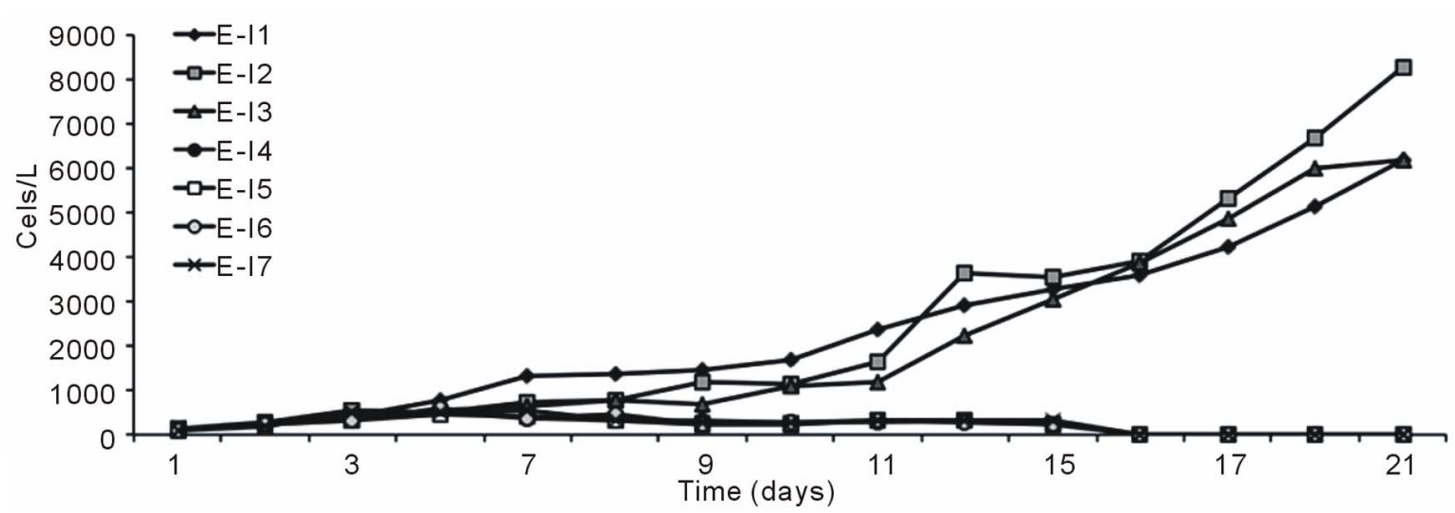

(a)

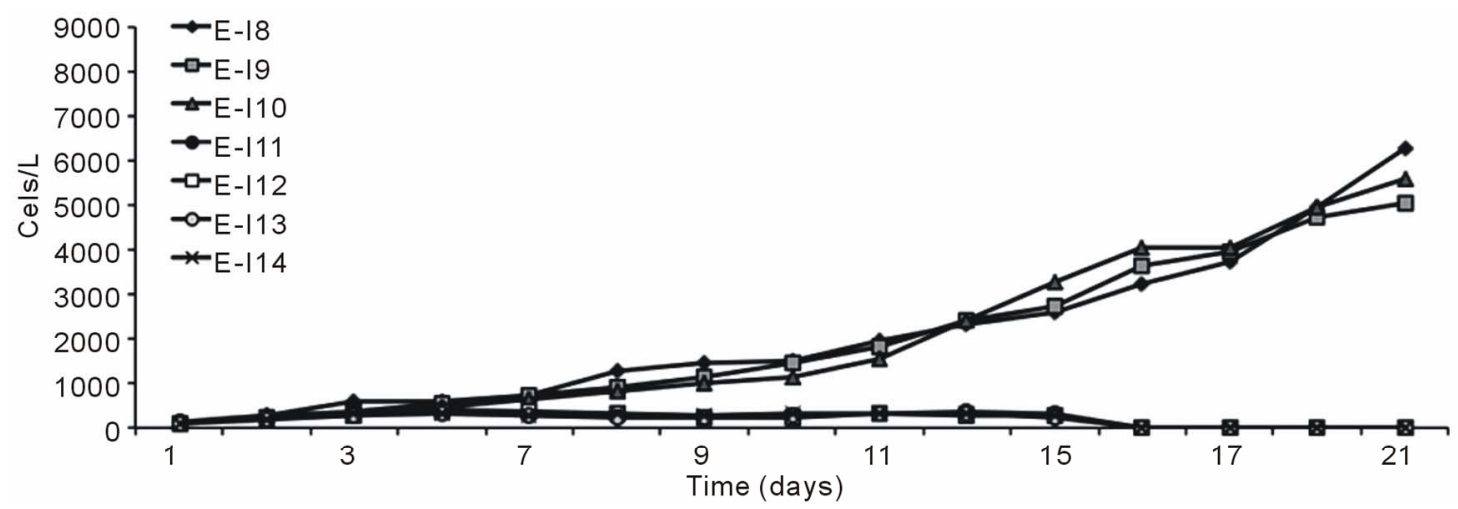

(b)

Figure 1. Growth curves of Dunaliella salina SA32007, varying salinity as $\mathrm{NaCl}$ concentration. (a) N/P ration equal to $14 / 1$; (b) N/P ration equal to $25 / 1$. Each point of growth curve was obtained from triplicated data. Standard deviation values were less than $5 \%$.

that cells content in the BLP-treatments E-II3, E-II7 and E-II11, was higher than their counterparts E-II4, E-II8 and E-II12, corresponding to ALP-treatments. From the fourteen treatments examined those cultured with a N/P ratio of 14/1 (E-II3 and E-II4) exceeded the 10,000 Cells/L, near to reference value or control with bubbling (E-II1). Figure 2(b) indicates the growth curves of treatments without air bubbling, for both BLP and ALP treatments. Main BLP-treatments with bubbling presented higher cells content than those ALP-treatments with bubbling. However, this trend was not exhibited for the case of Not Bubbled treatments. Table 4 summarize the different treatment effects on the kinetic parameters of the experimental strain. The highest $\mu$ values were found in E-II1 (Bb-control), E-II4 (N/P ratio of 14/1, ALP and bubbled) and E-II12 (N/P ratio of 0.5/1, ALP and bubbled). Statistically, no significant correlation was found between $\mathrm{K}$ and $\mu(\mathrm{r}=0.254, \mathrm{p}>0.05)$ among treatments.

\subsection{Determination of Total Extractable Lipids}

Figures 3(a) and (b) show the results of \%TELs for BLP-treatments with and without air bubbling. On day 6 ,
Table 4. Culture conditions and kinetic parameters to $\mathrm{Du}$ naliella salina SA32007 in experimental II.

\begin{tabular}{|c|c|c|c|c|c|c|}
\hline \multicolumn{7}{|c|}{ Culture Conditions and Kinetic Parameters } \\
\hline Treatment & $\begin{array}{l}\mathrm{N} / \mathrm{P} \\
\text { Ratio }\end{array}$ & $\begin{array}{l}\text { Application } \\
\text { Nitrogen } \\
\text { Deficiency }\end{array}$ & $\begin{array}{c}\text { Air } \\
\text { Bubbling }\end{array}$ & $\begin{array}{c}\text { Maximum } \\
\text { Algae } \\
\text { Density K } \\
\text { (cell/L) }\end{array}$ & $\begin{array}{c}\text { Time } \\
\text { Generation } \\
g \text { (days) }\end{array}$ & $\begin{array}{l}\text { Growth } \\
\text { Rate } \\
\mu\left(\mathrm{d}^{-1}\right)\end{array}$ \\
\hline "E-II1 & $25 / 1$ & BLP & $\mathrm{Bb}$ & 20,594 & 3 & 0.23 \\
\hline${ }^{*} \mathrm{E}-\mathrm{II} 2$ & $25 / 1$ & BLP & $\mathrm{NBb}$ & 10,625 & 10 & 0.07 \\
\hline E-II3 & $14 / 1$ & BLP & $\mathrm{Bb}$ & 24,344 & 4 & 0.17 \\
\hline E-II4 & $14 / 1$ & ALP & $\mathrm{Bb}$ & 13,562 & 3 & 0.23 \\
\hline E-II5 & $14 / 1$ & BLP & $\mathrm{NBb}$ & 12,474 & 6 & 0.12 \\
\hline E-II6 & $14 / 1$ & ALP & $\mathrm{NBb}$ & 8875 & 4 & 0.17 \\
\hline E-II7 & $05 / 1$ & BLP & $\mathrm{Bb}$ & 7219 & 11 & 0.06 \\
\hline E-II8 & $05 / 1$ & ALP & $\mathrm{Bb}$ & 5688 & 10 & 0.07 \\
\hline E-II9 & $05 / 1$ & BLP & $\mathrm{NBb}$ & 10,469 & 4 & 0.17 \\
\hline E-II10 & $05 / 1$ & ALP & $\mathrm{NBb}$ & 13,531 & 4 & 0.17 \\
\hline E-II11 & $0.5 / 1$ & BLP & $\mathrm{Bb}$ & 2375 & 4 & 0.17 \\
\hline E-II12 & $0.5 / 1$ & ALP & $\mathrm{Bb}$ & 3375 & 3 & 0.23 \\
\hline E-II13 & $0.5 / 1$ & BLP & $\mathrm{NBb}$ & 7812 & 12 & 0.06 \\
\hline E-II14 & $0.5 / 1$ & ALP & $\mathrm{NBb}$ & 14,656 & 12 & 0.06 \\
\hline
\end{tabular}

Abbreviators: Bubbled (Bb); Not Bubbled (NBb); Before Lag Phase (BLP); After Lag Phase (ALP). ${ }^{*}$ Control conditions: E-II1: N/P ration of 25/1, Before Lag Phase (BLP), Bubbled (Bb) and salinity of $0.5 \mathrm{M}$ as NaCl. E-II2: N/P ration of 25/1, Before Lag Phase (BLP), Not Bubbled (NBb) and salinity of $0.5 \mathrm{M}$ as $\mathrm{NaCl}$. 


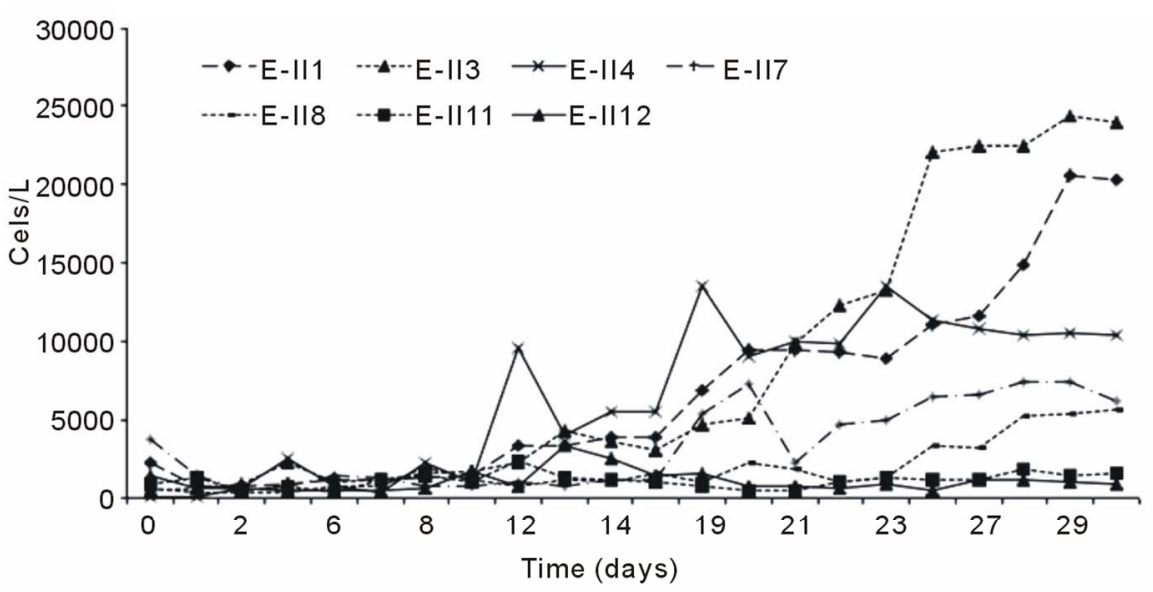

(a)

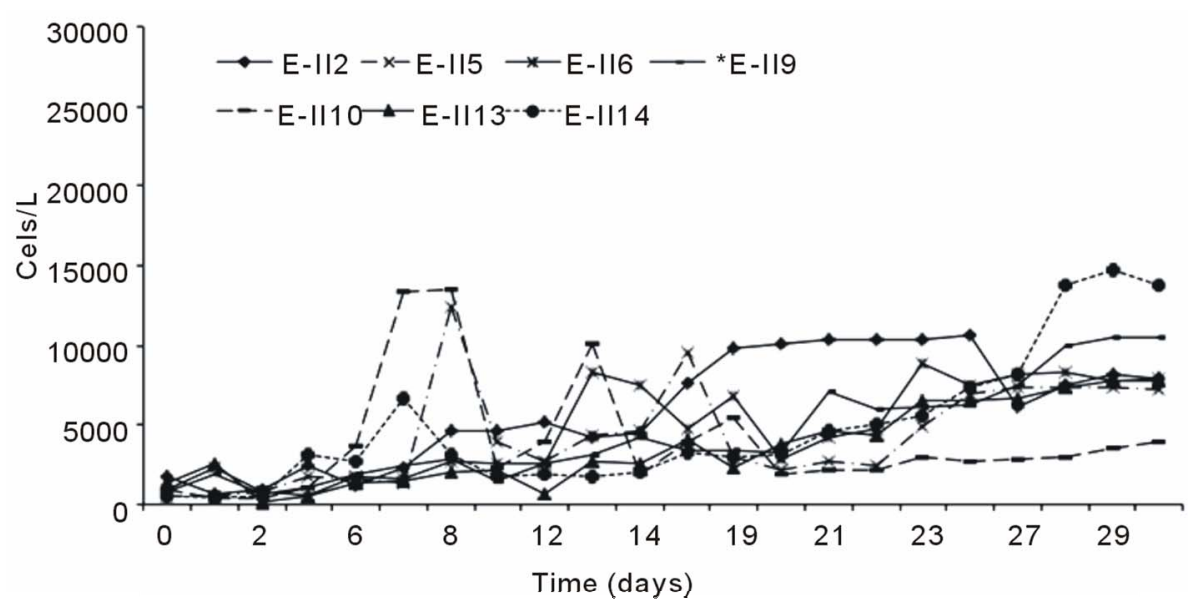

(b)

Figure 2. Bubbling effect on Dunaliella salina SA32007 cultures growth under different treatments. (a) Bubbled treatments; (b) No Bubbled treatments. Each point of growth curve was obtained from triplicated data. Standard deviation values were less than $5 \%$.

the Bb-treatments E-II3, E-II7 and E-II11, presented $\%$ TELs of $21 \%, 37 \%$ and $13 \%$, respectively (Figure 3(a)).

From day 7 onward, the \%TELs decreased in most cases, with the exception of E-II3 on day 20 when it reached $44 \%$. In general, the NBb-treatments showed lower values of \%TELs than Bb-treatments (Figures 3(a)-(d), showing significant values for the difference of medians (Mann-Whitney; $\mathrm{p}=0.0209$ ). Moreover, most treatments with a N/P ratio of 14/1 showed higher values of \%TELs than the rest of N/P ratios. An interesting fact was observed for 14/1 N/P ration of bubbled treatments at day 20, when maximum values of \%TELs were reached for both types of treatments BLP and ALP (Figures 3(a) and (c)). A further highlight was observed for the 5/1 N/P ration of ALP-treatments with and without bubbling (E-II8 and E-II10) where the \%TELs remained relatively stable between days 6 to 20, and increasing on day 27.

\subsection{Quantification of Triglycerides}

The Figure 4(a), shows the \%TAGs for BLP-treatments with bubbling. It was observed that \%TAGs for Bb-control (E-II1), gradually increased over time, ranging from $42 \%$ to $55 \%$. The $\%$ TAGs obtained in E-II3 were higher than Bb-control (E-II1) and E-II7. The treatment E-II11 showed a decrease over time compared to the Bb-control (E-II1).

For ALP-treatments with bubbling, the E-II4 showed $\%$ TAGs ranging from $53 \%$ to $56 \%$, which was higher than Bb-control (range $40 \%$ to $54 \%$ ). By the contrary, the E-II8 and E-II12 presented \%TAGs lower than Bb-control. However, both declined gradually over time, from $20 \%$ to $1 \%$ and $8 \%$ to $4 \%$, respectively (Figure $4(\mathbf{b})$ ). Likewise, the \%TAGs of NBb-control (E-II2) and E-II5, decreased gradually over time, in ranges from $28 \%$ to $0 \%$ and $37 \%$ to $3 \%$, respectively (Figure $4(\mathbf{c})$ ). The E-II9 treatment showed no particular trend in time. Between days 6 and 20 of the experiment, the \%TAGs 
values remained constant for E-II13, decreasing on day $27 \%$ to $1.6 \%$ (Figure $4(\mathbf{c})$ ). The $\%$ TAGs of ALP-treatments without bubbling (E-II6, E-II10 and E-II14), and the $\mathrm{NBb}$-control (E-II2) tended to decrease gradually over time (Figure 4(d)). However, \%TAGs values in $\mathrm{NBb}$-control were always higher than those measured in nitrogen-limited treatments E-II6, E-II10 and E-II14

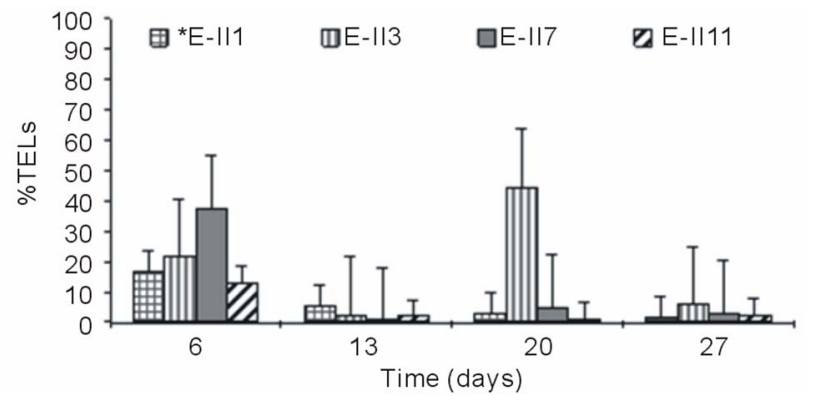

(a)

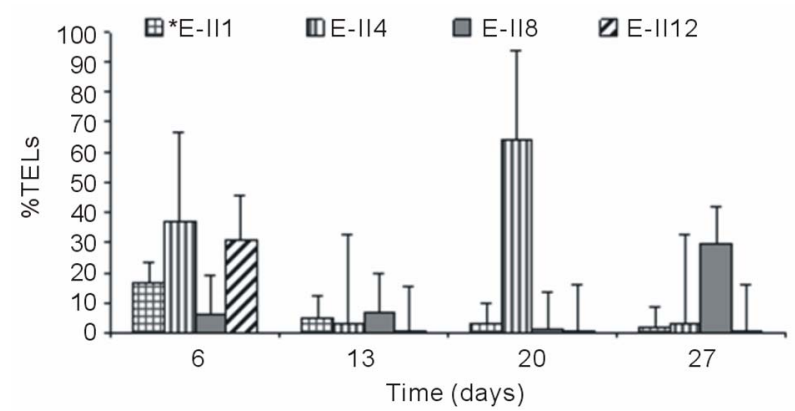

(c)

\section{(Figure 4(d)).}

The overall effect was statistically determined comparing the \% TAGs from treatments with (E-II3 to E-II14) and without nitrogen limitations (controls) through a non-parametric test (Mann-Whitney). According to the statistical test results, nitrogen-limitations treatments showed significantly higher \%TAGs than the controls

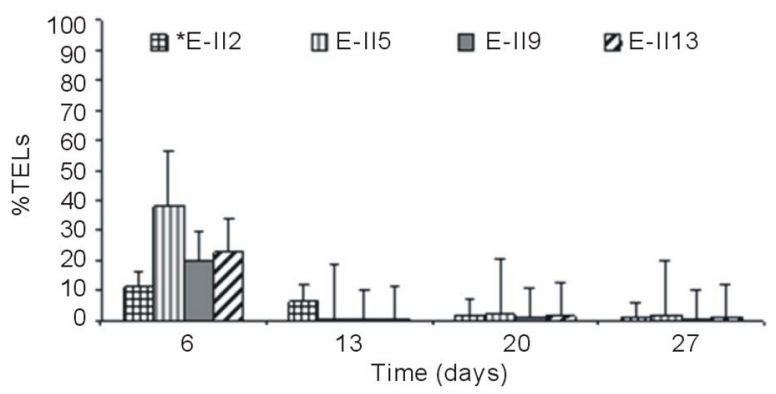

(b)

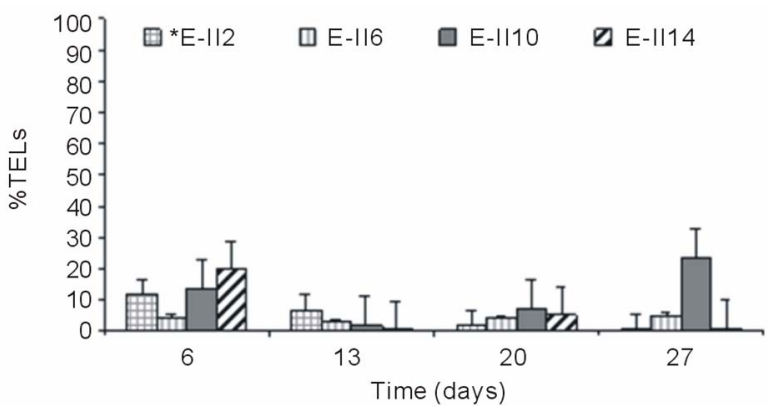

(d)

Figure 3. Total extractable lipids percent (\%TELs) for different treatments, varying the N/P ration. (a) BLP, bubbled treatments; (b) BLP, no bubbled treatment; (c) ALP, bubbled treatments; (d) ALP, no bubbled treatments.

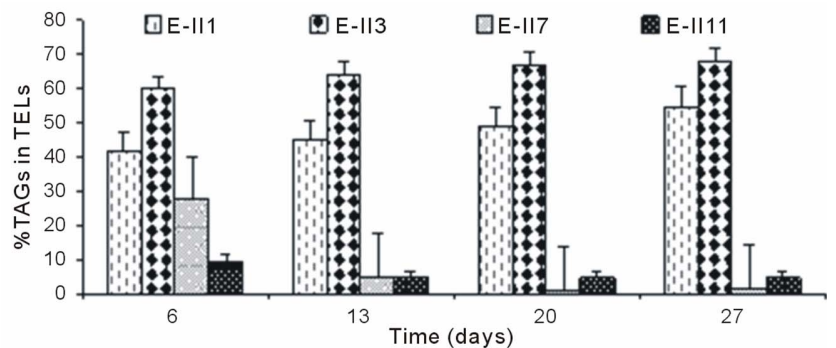

(a)

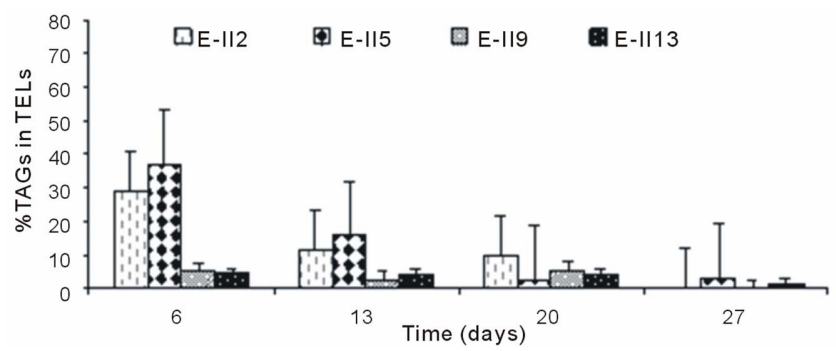

(c)

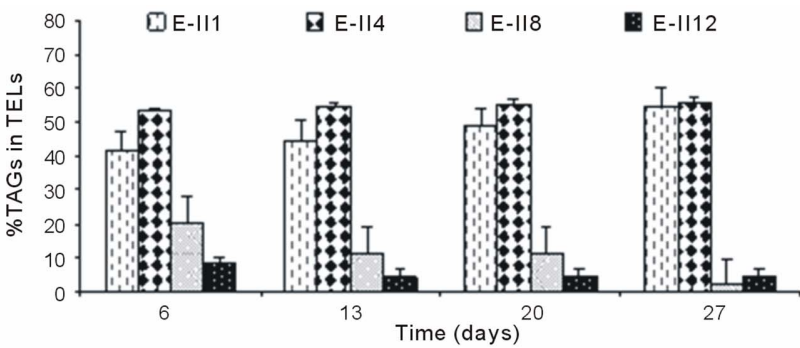

(b)

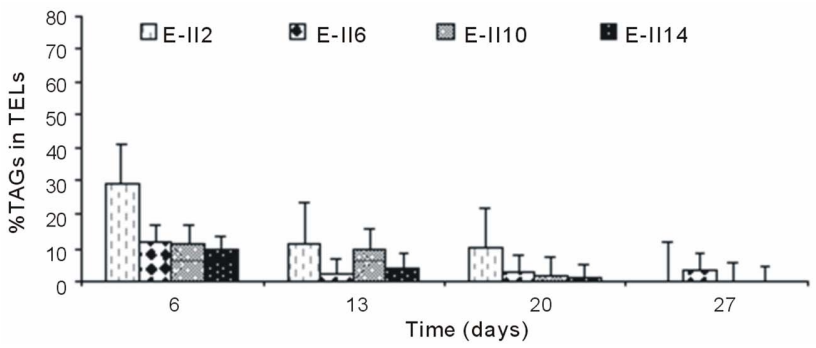

(d)

Figure 4. Triglyceride percent in total extractable lipids (\%TAGs in TELs) for different treatments, varying the N/P ration. (a) BLP, bubbled treatments; (b) ALP, bubbled treatments; (c) BLP, no bubbled treatments; (d) ALP, no bubbled treatments. 
(Mann-Whitney, $\mathrm{p}=0.004$ ).

\section{DISCUSSION}

\subsection{Effect of Salinity}

Although several reports indicated the D. salina Teodoresco capacity of growing in a wide range of salinity [30-33], salinities greater than $1 \mathrm{~mol} / \mathrm{L} \mathrm{NaCl}$ (Figure 1) produced a reduction of microalgae biomass at present assays. This result could be related to two factors; first, the D. salina SA32007 strain used for the experiments was cultivated for more than three years in a Johnson Standard medium with a salinity of $0.5 \mathrm{~mol} / \mathrm{L}$ of $\mathrm{NaCl}$ $[25,34]$. These culture conditions favoured the expression of a phenotype less tolerant to the extreme salinity, a factor that characterizes the site of isolation of the originnal strain. Second, the isolation site presents complex environmental conditions, with wide daily ranges of temperature and light and a complex water chemistry [35], which were only partially replicated in the laboratory. These conditions could limit the strain growth. In general terms, it is referred to as the "bottle effect", which is the set of experimental variables that decrease vital functions and properties of growth in a body, when it is moved from its natural environment to an experimental one [36]. Our observations of microalgae biomass reduction under saline lab-conditions greater than $1 \mathrm{~mol} / \mathrm{L}$ agree with the one reported by Cifuentes et al. (1992) for D. salina Teodoresco from the subtropical South American hypersaline environments.

\subsection{Effect of Nitrogen Limitation, Nitrogen Deficiency and Air Bubbling}

It was noted that the microalgae biomass of main bubbled BLP-treatments (Figure 2(b)) was greater than the biomass of those held under the same conditions but in which the nitrogen deficiency was applied after the lag phase (Figure 2(b)). This behaviour is probably due to that the cultures to which we applied the nitrogen deficiency before lag phase, had to overcome only one metabolic adjustment to new environmental conditions, which included at the same time the adaptation to new medium conditions and to limitation in nitrogen. In comparison, microalgae subjected to the ALP-treatment have been subjected to two consecutive metabolic adjustments, first the adaptation to new medium conditions and later the limitation in nitrogen. The addition of these two adaptations includes, among others, changes in the expression of genes, the concentration of intracellular metabolites and the neutralization of toxic compounds in the new media $[10,17,18]$. As a consequence of this metabolic adjustment, normally, the algae suppress their reproduction and derive energy (as ATP) from the metabolic proc- esses $[19,28]$. For Not Bubbled treatments, the lack of an external $\mathrm{CO}_{2}$ source (Bubbling), inhibited the biomass increment of cultures, independently of the limitation in Nitrogen applied after or before the latent phase. These results coincide with the description for the microalgae Neochloris oleoabundans, under a similar protocol of nitrogen deficiency [9].

The application of different levels of nitrogen deficiency represented by changes in the N/P ratio, would have caused reductions in growth culture rate $(\mu)$. This effect was much more acute in the case of cultures with $\mathrm{N} / \mathrm{P}$ ratios below $5 / 1$. Furthermore, in these cultures cell death could be occurring and therefore, a reduction of the microalgae biomass [36]. Otherwise, concerning N/P ratio of 14/1, some authors state that under these nonacute scarcity conditions, microalgae are capable of turning degrading pathways of nitrogen compounds, which would maintain a sufficient pool of intracellular nitrogen for its reproduction [37].

Contrary to that observation most of the time in microalgae cultures maintained under controlled laboratory conditions [38], there was a lack of correlation between $r$ and $\mathrm{K}$. This could be expressing the individual or combined effect of some limiting conditions tested in this study. Additional tests are needed to clarify the effect of the variables tested in the present study on the kinetic parameters in the case of D. salina SA32007.

\subsection{Effect of Nitrogen Deficiency and Bubbling on the Content of Extractable Lipids and Triglycerides}

In time, all NBb-treatments limited by BLP nitrogen showed a reduction in lipid content. This behaviour could be the result of a biochemical response of microalgae to the shortage of a direct source of $\mathrm{CO}_{2}$, as reported by Mendoza and Molina, 2008 [10] in the case of the marine microalgae Crypthecodinium conil. This way, shortage of $\mathrm{CO}_{2}$ would stimulate the microalgae to use alternative carbon sources, such as molecules from degradation of lipids, for their vital activities like as membrane building, plastid regeneration and photosynthesis $[2,28,39]$. The above mentioned observation is also sustained by the fact that, under stress conditions, lipids are the most abundant macromolecules because they prevent photooxidative stress [2,40-42]. Furthermore, the lack of bubbling could generate the inefficient distribution of nutriaents in the medium, due to a limitation in the mixing. As a consequence of that, it could generate a metabolic detrimental and a growth suppression of microalgae [24].

The \%TELs achieved in ALP-treatment were lower than those reported in treatments subjected to BLP nitrogen deficiency. This would be related to the smaller 
amount of biomass obtained from the first cultures and therefore, a smaller amount of lipids. Moreover, as quoted above, the cultures to which nitrogen deficiency was applied after the latency phase, had to experience two processes of metabolic adjustment, thereby limiting energy for cell reproduction [9].

Taking into account all the treatments, the cultures subjected to a slight nitrogen deficiency with a N/P of 14/1 (E-II3 and E-II4), presented the highest values of total extractable lipids and triglycerides. Moreover, other limiting treatments $(5 / 1$ and $0.5 / 1)$, being able to stimulate the synthesis of lipids $[14,43,44]$, suffered a severe physiological restriction, which prevented them to express such stimulation. Then, there exists a nitrogen limitation threshold under which the strain would not be able to increase the concentration of lipids due to a metabolic block [45]. Contrary to what has been observed in other microalgae, D. salina Teodoresco is not capable of fixing gaseous nitrogen by means of an enzyme [46], therefore this nutrient shortage can only be mitigated by some external input of its environment.

It has been stated that, under nitrogen limitation, microalgae can activate protection mechanisms like the modification of lipid metabolism, since the diacilglicerolaciltransferase enzyme can turn it into acetyl CoA and TAGs $[2,11,14,44]$. Thus, microalgae would be able to generate reservoirs of neutral lipids in the form of TAGs, which could be stored for the reconstruction of chloroplast membranes or mainly as sources of carbon $\left(\mathrm{CO}_{2}\right)$ and energy [13]. In this regard, the limited treatments in $\mathrm{N} / \mathrm{P}$ of $0.5 / 1$ and $5 / 1$ showed a gradual decrease of TAGs over time, which would suggest their use as carbon sources with growth purposes.

In summary, these results shown that maximum values of microalgal biomass and TAGs (in total lipids), can be achieved when the culture conditions combination includes $0.5 \mathrm{M}$ of $\mathrm{NaCl}$; N/P of $14 / 1$ and the application of nitrogen deficiency before the lag phase.

Finally, these findings are of utmost importance in order to gain insight in the limited knowledge of microalgae from the Chilean Altiplane and of their development as biotechnological sources such as biodiesel production and cosmetic and pharmaceutical applications, in which lipid production becomes a key factor.

\section{ACKNOWLEDGEMENTS}

We would like to extend our gratitude to Karina Diez de Medina for the microalgae culture maintenance and to Irma Vila Pinto for her critical appraisal of the manuscript. This study was sponsored by Minera Escondida Ltda. through Project MEL 08/09: "Estudio de prefactibilidad técnica del uso de Dunaliella salina SA32007, como fuente en la producción de Biodiesel". Diana Arias Forero and Gladys Hayashida Soiza were financially supported by grants of the Chemical Sciences Magis- ter Program of the Universidad Católica del Norte and a doctoral fellowship of CONICYT (Government of Chile), respectively.

\section{REFERENCES}

[1] Pulz, O. and Gross, W. (2004) Valuable products from biotechnology of microalgae. Applied Microbiology and Biotechnology, 65, 635-648. doi:10.1007/s00253-004-1647-x

[2] Qiang, H., Sommerfeld, M. and Jarvis, E. (2008) Microalgal: Triacylglycerols as feedstocks for biofuel production: Perspective and advances. The Plant Journal, 54, 621-639. doi:10.1111/j.1365-313X.2008.03492.x

[3] Song, D., Fu, J. and Shi, D. (2008) Exploitation of oilbearing microalgae for biodiesel. Chinese Journal of Biotechnology, 24, 341-348.

doi:10.1016/S1872-2075(08)60016-3

[4] Chisti, Y. (2007) Biodiesel from microalgae. Biotechnology Advances, 25, 294-306. doi:10.1016/j.biotechadv.2007.02.001

[5] Kishimoto, M., Okakura T., Nagashima, H., Minowa, T., Yokoyama, S. and Yamaberi, K. (1994) $\mathrm{CO}_{2}$ fixation and oil production using micro-algae. Journal of Fermentation and Bioengineering, 78, 479-481. doi:10.1016/0922-338X(94)90052-3

[6] Brown, L. and Zeiler, K. (1993) Aquatic biomass and carbon dioxide trapping. Energy Conversion and Management, 34, 1005-1013. doi:10.1016/0196-8904(93)90048-F

[7] Metting, F.B. (1996) Biodiversity and application of microalgae. Journal of Industrial Microbiology, 17, 477489. doi:10.1007/BF01574779

[8] Hui, C. and Jiang, J. (2009) Mini-review. Osmotic responses of Dunaliella to the changes of salinity. Journal of Cellular Physiology, 219, 251-258. doi: $10.1002 /$ jep. 21715

[9] Li, Y.Q., Horsman, M., Wang, B. and Wu, N. (2008) Effects of nitrogen sources on cell growth and lipid accumulation of green alga Neochloris oleabundans. Applied Microbiology and Biotechnology, 81, 629-636. doi:10.1007/s00253-008-1681-1

[10] Mendoza, H. and Molina, C. (2008) Variación cuantitativa de la composición en ácidos grasos de Crypthecodinium conil en condiciones de supresión de nitrógeno. Grasas y aceites, 59, 27-32.

[11] Takagi, M., Karseno, Y. and Yoshida, T. (2006) Effect of salt concentration on intercellular accumulation of lipids and triacylglyceride in marine microalgae Dunaliella cells. Journal Bioscience and Bioengineering, 101, 223226. doi: $10.1263 / \mathrm{jbb} .101 .223$

[12] Meyer, B. and Oettl, B. (2005) Effects of short-term starvation on composition and metabolism of larval Antarctic krill Euphausia superb. Marine Ecology Progress, 292, 263-270. doi:10.3354/meps292263

[13] Kumar, S., Uma, L. and Subramanian, G. (2003) Nitrogen stress induced changes in the marine cyanobacterium Oscillatoria willei. BDU 130511. FEMS Microbiology Ecology, 45, 263-272. 


\section{doi:10.1016/S0168-6496(03)00162-4}

[14] Yamaberi, K., Takagi, M. and Yoshida, T. (2000) Limited feeding of potassium nitrate for intracellular lipid and triglyceride accumulation of Nannochloris sp. UTEX LB1999. Applied Microbiology and Biotechnology, 54, 112-117. doi:10.1007/s002530000333

[15] Xing-Qing, X. and Beardall, J. (1997) Effect of salinity of fatty acid composition of a green microalga from an Antarctic hypersaline lake. Photochemistry, 45, 655-658. doi:10.1016/S0031-9422(96)00868-0

[16] Garnham, G.W., Codd, G.A. and Gadd, G.M. (1992) Kinetic of uptake and intracellular location of cobalt, manganese and zinc in the estuarine green alga Chlorella salina. Biotechnology, 37, 270-276.

[17] Williams W.D. (1998) Salinity as a determinant of the structure of biological communities in salt lakes. Hydrobiology, 381, 191-201. doi:10.1023/A:1003287826503

[18] González, J. and Peña, A. (2002) Estrategia de adaptación de microorganismos halófilos y Debaryomyces hansenii (Levadura halófila). Revista Latinoamericana de Microbiología, 44, 44-45.

[19] Harwood, J. and Guschina, I. (2009) The versatility of algae and their lipid metabolism. Biochemistry, 91, 679684. doi:10.1016/j.biochi.2008.11.004

[20] Gomez, P., González, M. and Becerra, J. (1999) Quantity and quality of b-carotene produces by two strains of $\mathrm{Du}$ naliella salina (TEODORESCO 1905) from the Northern Chile. Boletín de la Sociedad Chilena de Química, 44, 463-468.

[21] Kopecký, J., Schoefs, B., Loest, K., Štys, D. and Pulz, O. (2000) Microalgae as a source for secondary carotenoid production: A screening study. Algological Studies, International Journal of Phycological Research, 133, 153168.

[22] Orosa, M., Torres, E., Fidalgo, P. and Abalde, J. (2000) Production and analysis of secondary carotenoids in green algae. Journal of Applied Phycology, 12, 553-556. doi:10.1023/A:1008173807143

[23] Ben-Amotz A. (2004), Industrial production of microalgal cell-mass and secondary products-major industrial species. Handbook of Microalgal Culture: Biotechnology and Applied Phycology, 273.

[24] González de Molina, Dr. M. (2011) Technical paper SEAE: Series introduction to agroecology: The fertilization and balance of nutrients in agroecological systems. Spanish Society for Organic Farming (SEAE), Catarroja, Valencia, 1-24.

[25] Johnson, M.K., Johnsone, J., Macelroyr, L., Speerh, L. and Bruffb, S. (1968) Effects of salts on the halophilic alga Dunaliella viridis. Journal of Bacteriology, 95, 14611468.

[26] Kampf, S.K. and Tyler, S.W. (2005) Spatial characterization of evaporation and land surface energy fluxes at the Salar de Atacama, Northern Chile using ASTER image classification. Advances in Water Resources, 29, 336354. doi:10.1016/j.advwatres.2005.02.017

[27] Bligh, E.G. and Dyer, W.J. (1959) A rapid method for total lipid extraction and purification. Canadian Journal
Biochemistry and Physiology, 37, 911-917. doi:10.1139/059-099

[28] Ben-Amontz, A., Tornabene, T. and Thomas, W. (1985) Chemical profile of selected species of microalgae with emphasis on lipids. Journal Phycology, 21, 72-81. doi:10.1111/j.0022-3646.1985.00072.x

[29] Mann, H.B. and Whitney, D.R. (1947). On a test of whether one of two random variables is stochastically larger than the other. Annals of Mathematical Statistics, 18, 5060. doi:10.1214/aoms/1177730491

[30] Serpa, R. and Calderon, A. (2005) The effect of salinity stress in forth strains of Dunaliella salina TEOD in Perú. Ecología Aplicada, 4, 127-133.

[31] Joyce, L., Stuart, D. and Duncan, A. (1977) The salt relations of Dunaliella. Microbiology, 113, 131-138.

[32] Cifuentes, A., González, M., Conejeros, M., Dellarosa, V. and Parra, O. (1992) Growth and carotenogenesis in eighth straits of Dunaliella salina teodoresco from Chile. Journal of Applied Phycology, 4, 111-118. doi:10.1007/BF02442459

[33] Ben-Amontz, A. and Avron, M. (1975) Adaption of the unicellular alga Dunaliella parva to a saline environment. Journal of Phycology, 11, 50-54.

[34] Oren, A. (2005). A hundred years of Dunaliella research: 1905-2005. Saline Systems, 1, 1-14. http://www.aquaticbiosystems.org/content/1/1/2

[35] Alonso, H. and Risacher, F. (1996) The Salar de Atacama Geochemistry, part 1: The origen of components and saline balance. Revista Geológica de Chile, 23, 113-122.

[36] Hammes, F., Vital, M. and Egli, T. (2010) Critical evaluation of the volumetric "bottle effect" on microbial batch growth. Applied Environmental Microbiology, 76, 12781281. doi:10.1128/AEM.01914-09

[37] Lara, M. and García, E. (2007) La utilidad experimental y los procesos desencadenados por el sometimiento de los organismos a condiciones de hambruna. Encuentros en la Biología, 121, 2. http://www.encuentros.uma.es/encuentros121/121.pdf

[38] Xin, L., Hong-Ying, H. and Yu-Ping, Y. (2011) Growth and lipid accumulation properties of a freshwater microalga, Scenedesmus sp. under different cultivation temperature. Bioresource Technology, 102, 3098-3102. doi:10.1016/j.biortech.2010.10.055

[39] Cohen, Z. and Khozin-Golberg, I. (2000) The role of triacylglycerol as a reservoir of polyunsaturated fatty acids for the rapid production of chloroplastic lipids in certain microalgae. Biochemical Society Transactions, 28, 740743. doi:10.1042/BST0280740

[40] Mendoza, H., Martel, A., Jiménez del Río, M. and García, G. (1999) Oleic acid is the main fatty acid related with carotenogenesis in Dunaliella salina. Journal of Applied Phycology, 11, 15-19. doi:10.1023/A:1008014332067

[41] Hernández, L., Quintana, M. and Morris, H. (2000) Obtención de glicerol a partir de la microalga Dunaliella salina. Revista Cubana de Farmacia, 34, 134-137.

[42] Ben-amontz, A., Katz, A. and Avron, M. (1982) Accumulation of beta-carotene in halotolerant algae: Purification and characterization of beta-carotene rich globules 
from Dunaliella bardawill (Chlorophyceae). Journal of Phycology, 18, 529-537.

doi:10.1111/j.1529-8817.1982.tb03219.x

[43] Zhila, N., Kalacheva, G. and Volova, T. (2005) Influence of nitrogen deficiency on biochemical composition of the green alga Botryococcus. Journal of Applied Phycology, 17, 309-315. doi:10.1007/s10811-005-7212-x

[44] Yamaberi, K., Takagi, M. and Yoshida, T. (1998) Nitrogen depletion for intracellular triglyceride accumulation to enhance liquefaction yield of marine microalgal cell into fuel oil. Journal of Marine Biotechnology, 6, 44-48.

[45] Fidalgo, J.P., Cid, A., Torres, E., Sukenik, A. and Herrero,
C. (1998) Effects of nitrogen source and growth phase on proximate biochemical composition, lipid classes and fatty acid profile of the marine microalga Isochrysis galbana. Aquaculture, 166, 105-116. doi:10.1016/S0044-8486(98)00278-6

[46] Giordano, M. and Beardall, J. (2009) Impact of environmental conditions on photosynthesis, growth and carbon allocation strategies of hypersaline species of Dunaliella. Global NEST Journal, 11, 79-85.

http://www.gnest.org/journal/Vol11_No1/79-85 566 Gio $\underline{\text { rdano.pdf }}$ 